\title{
MINORITY VETO RIGHTS IN KOSOVO’S DEMOCRACY
}

\author{
BEHAR SELIMI ${ }^{1}$
}

\begin{abstract}
The political system of Kosovo belongs to the power sharing democracies. Indeed, it has all the characteristics of Consociational Democracy. In addition to that, minority veto rights are absolute and go above the aims of this type of democracy. As it is designed in current Constitutional arrangements, even a single word of Constitution can't be changed without minorities' vote. This is different from other Consociational Democracies, where minorities are entitled with selected veto power only regarding their vital interests, but they cannot block constitutional decision-making. Since Kosovo is among the youngest countries worldwide, this constitutional provision can be a heavy obstacle even in the state building efforts of majority. Therefore, in this article we will try to explain in depth this constitutional arrangement versus principles of sharing power systems and versus similar democracies in the region and wider. The doctrinal constitutional interpretation, descriptive and comparative methods are the main pillars of research methodology.
\end{abstract}

Keywords: Kosovo, Constitution, Minority, Veto Rights, Consociational Democracy, Sharing Power.

Summary: I. INTRODUCTION; II. THE RIGHT OF VETO OF MINORITIES IN KOSOVO; III. A REGIONAL LEVEL COMPARISON; III.1.Bosnia and Herzegovina; III.2.Republic of North Macedonia; IV. ConCLUSIONS.

\section{INTRODUCTION}

The political system of Kosovo belongs to the power sharing democracies. The governance system in Kosovo is a distinct model of democracies with powers shared among the communities, namely derivative of the consensus theory. Considering the way of creation and the structure of power, certain authors, in an effort to find a correct label, call this system of governance a "community state" or a "concessional state" (Ramadani, 2009). These label names, which are essentially the same, are based on a system of governance analysis based on the consensus theory and the Comprehensive Proposal for the Ahtisaari's Kosovo Status Agreement. ${ }^{2}$ Although Kosovo represents a typical case of homogenous society, ${ }^{3}$ the document emerged from the multiethnic concept and hence it recommended a divided democracy.

1 Lecturer, PhD, Faculty of Law, University of Business and Technology, Prishtina, Kosovo (behar.selimi@ubt-uni.net).

2 The plan was named after the UN Special Representative, former Finnish President Martti Ahtisaari, who led the one-year (2006-2007) talks between Kosovo and Serbia. For this document see: https://www.kuvendikosoves.org/common/docs/Comprehensive\%20Proposal\%20.pdf

3 Since 1981, Kosovo has been inhabited by more than $80 \%$ of Albanians, and on the eve of the war by $88 \%$. Since the last census of 2011, boycotted by the four northern municipalities, it turns out that Kosovo is inhabited by over $90 \%$ Albanian. So, unlike the states (Macedonia and Bosnia and Herzegovina), which represent genuine multiethnic societies, or other multi-cultural and multiethnic countries (Ireland, Belgium, Lebanon, etc.), in which the model of Consciousness Democracy was used.

See:http://worldpopulationreview.com/countries/kosovo-population/(Available 11.04.2019)

https://www.indexmundi.com/kosovo/demographics_profile.html (Available 11.04.2019) 
According to Arend Ljiphart, the conscious democracy has four features: broad coalition government, reciprocal veto, proportional representation and segmental autonomy (Ljiphart, 1977, p. 25). This model of governance is recommended for deep ethnic, religious and cultural societies, and especially post-conflict societies. Rather than recommended, in the new democracies in the Western Balkans (Bosnia and Herzegovina, North Macedonia and Kosovo), this model of power organization has been imposed by international actors, as of no alternative (Bieber and Keil, 2009, p. 312). In Kosovo, some authors do not consider it a purely consensual model, as the representatives of the communities in the government do not have the right to veto and the fact that they did not have the right to veto in the initial constitutional approval; also because Kosovo, unlike Bosnia Herzegovina, has an individual president (Korenica, F. i Doli, no date). They consider that on these issues, the Kosovo constitution accepts a fundamentalist approach. Indeed, the integralists do not deny cultural differences. They only aim to establish common public institutions irrespective of ethnic and other differences (Interim Agreement for Peace and Self-Government in Kosovo, 1999, pp. 41-51).

The first consociational mechanisms in relation to Kosovo are found in the Draft of the Rambouillet Accord (Interim Agreement for Peace and Self-Government in Kosovo, 1999), which was accepted by the Kosovo side, but not by the Serbian side and then also in the Constitutional Framework for Provisional Self-Government in (UNMIK/REG/2001/9, 2001) and, finally, by the current Constitution of Kosovo (2008).

The Constitution outlines all the provisions of the Ahtisaari's comprehensive Proposal on the status for Kosovo, which promote the divided power democracy, and even as we will see below, overcome the demands of conscientious democracy.

Regarding the broad coalition government and proportional representation as two of the first characteristics of this model of governance, the Constitution of Kosovo (Article 64 and Article 96) promotes executive and legislative conscience, as it guarantees the participation of at least two ministers and 4 deputy ministers in the government and at least 20 minority community members, of whom 10 should be of the Serb community (Kosovo Assambly, 2008). Moreover, if the government has more than 12 ministers, then a minister and 2 deputy ministers from the communities are added to the government. Proportional political representation of minorities is also applied in the leadership with the Assembly, as the Constitution requires the election of two vice presidents from the ranks of MPs representing minorities, of which one should belong to the Serbian minority, and the other from among the other non-majority communities.

Although Kosovo is not a typical multiethnic society, the application of the this model of consociational executive has produced results, especially in achieving common interethnic governance and more proportional representation (especially Serbian representation) of all communities in Kosovo. The best evidence is continual partipacipation of all minorities as requsted by Constitution, in each government from independence (2008) till actual (2019). 
Regarding representation in public institutions, the Constitution (Article 61) is clear in guaranteeing the right of non-majority communities to equal representation in public administration bodies and public enterprises. The right of representation in the police service in residential areas with non-majority communities is particularly emphasized. The Law on Civil Servants of 2010 defines, even more clearly, the right of representation of non-majority communities in public administration, reserving for them at least $10 \%$ of public posts (Kosovo Assambly, 2010).

A similar situation prevails also with proportional representation at the local level of government, but we will only be limited to the central level, as our main topic is not representation. It is worth adding to the fact that the first amendment to the Kosovo Constitution strengthens the position of non-majority communities, participation in public life and decision-making, allowing for measures or actions of affirmative politics (Kosovo Assambly, 2012).

Regarding non-territorial autonomy, as a prerequisite of consensus-based democracy, the Kosovo Constitution for non-majority communities guarantees three types of autonomy: personal autonomy, cultural autonomy and high degree of selfgovernment, especially in municipalities dominated by the Serb community. In these municipalities, the Law on Local Self-Government, in addition to its own and delegated competences, also guarantees enhanced competencies in the field of education, health and appointment of local police commanders (Kosovo Assembly, 2008) .

Like in other democracies of divided power, in Kosovo's democracy too, the non-majority communities are guaranteed the right of veto, which fulfills the framework of the preconditions of the country's economic democracy, even outweighing the current practices of this model, thus exacerbating more of an integration approach, though in favor of the minority. As we will see below, this right makes Kosovo's democracy a "conditioned democracy" by minorities and a barrier to the end of the process of making the state. Also, in comparison with similar democracies, we will see that this constitutional institute is currently the only one of this type, by which non-majority communities can block even changing of a single word of the constitution.

\section{THE RIGHT OF VETO OF MINORITIES IN KOSOVO}

The minority veto in Kosovo can be realized in two cases and within two types of the majority.

In the first case, Article 81 of the Constitution of Kosovo recognizes the right of minority communities to oppose adoption of laws that may violate their vital interests. There are 8 types of laws, for the adoption, amendment or abrogation of which most of the majority MPs present and voting are needed, as well as the majority of MPs who are present and voting. Mostly, these laws relate to education at all levels, use of languages, local elections, use of symbols, creation and termination of municipalities or the changing of their borders, extension of municipal power, and the laws for the enforcement of rights of communities and their members. Moreover, these laws cannot 
be subject to a referendum either. Popular sovereignty is limited to these laws, as the Constitution in Article 81, Paragraph 2, does not allow them to submit to a referendum. This type of minority veto right is typical of the conscious democracies and, as it is regulated by the constitution, promotes and guarantees the protection of the specific vital interests of the communities. Taking into account the guaranteed number of community representatives in the Assembly, minority veto rights also encourage their mobilization against the majority. In order to protect their vital interests, they should be present as much as possible in the Assembly at the time of voting and cooperate with each other, as the voting of the aforementioned laws can only be made if the majority of the minorities represented in parliament are present and vote. So, the vote of the majority of a community does not suffice, as a majority all community representatives represented in the Assembly is needed.

Ultimately, it can be said that this type of minority veto is in the function of interethnic political cohesion guaranteeing for a most advanced democracy for nonmajority communities. Fortunately, the traditional sensibility of the Albanian majority to non-majority communities in Kosovo has greatly influenced the veto on minority issues of vital interest to be accepted without any opposition, not only by the political representatives of the Albanian majority but also by ordinary citizens.

In the second case, the Constitution of Kosovo, in Article 114, requires that 2/3 of the members of the parliament vote for amending the Constitution, including 2/3 of the members of the parliament representing the non-majority communities. As the Assembly of Kosovo has 120 seats, of which 10 seats are guaranteed for representatives of the Serbian community and 10 for representatives of other non-majority communities, for amending the constitution, in whatever variant, at least the vote of 13 MPs of non-majority communities are needed. In the context of Kosovo, where representatives of the Serb community vote en bloc and are led by the leadership in Belgrade, the change of the Constitution on certain matters is impossible. For worse, the messages of UNMIK administrators for Kosovo under Resolution 1244 and the ongoing manipulation of Kosovo Serbs by Belgrade's political leaders have discouraged the integration of Serbs into Kosovo's institutions and hence the blocking of finalization processes of Kosovo's statehood. Blocking of the constitutional changes for the transformation of the Kosovo Security Force into an Army is just one example of how a minority veto can block the creation of national institutions that serve the common interest of all communities (Baliqi, 2018). Due to the specifics of the process of building Kosovo's statehood and because of its character, minority veto in Kosovo can be considered as an example and as an obstacle to the development of democracy, or an obstacle to the exercise of national sovereignty. In fact, one may conclude that, in a constitutional aspect, the majority in Kosovo is hostage to minority interests. Unlike the first type, this type of veto is a political and constitutional institute imposed by international and controversial even today, especially by the political representatives of the Albanian majority (Loncar, 2015). 


\section{A Regional LeVel Comparison}

Although there are numerous examples of reciprocal vetoes globally, for the needs of this paper we will be focused mainly to cases in the region that can be compared to the case of Kosovo, including occasional refrences to the countries with long mutual veto experience, like Belgium. Bosnia and Herzegovina and Macedonia are typical cases of democracies with sharing powers in which minorities are guaranteed the right of veto in all decisions that may affect their vital national interests.

\section{III.1.Bosnia and Herzegovina}

Bosnia and Herzegovina represents an unsuccessful example of a consociational democracy, for the fact that ethnic divisions with constitutional arrangements only deepened (Kasapovic, 2005). The current constitution and constitutional arrangements of the entities are reflections of the "Dayton Accords", which ended the four year war in Bosnia and Herzegovina. ${ }^{4}$ They were meant as temporary arrangements to ensure the transition from a controlled democracy to a consolidated democracy (Bojkov D. Victor, 2003).

The complexity of Bosnia and Herzegovina's constitutional political arrangements makes it difficult for a comparative analysis, as there is still a dilemma as to its naming, if it is a union of states, a federation or confederation respectively, so the veto right at the level of Bosnia and Herzegovina is a reciprocal veto of the of the three constituent ethnic communities in frame of two territorial political entities-federal unites. Due to this, and for the purpose of this paper, we will feel free to reduce the level of analysis and comparison at an entity level by calling Bosnia-Herzegovina, according to Professor Soren Keil , as a “ethnic federation sui generis” (Antonini, 2014).

At the confederal level, parliamentary decision-making, especially legislation, is based on the positive majority of the votes of the present and voting MPs, provided that at least one third of the representatives of each entity are present. According to the Constitution (Article 4, Paragraph 3), any decision of the Parliamentary Assembly may be declared destructive to vital interests by the majority of the delegates of one or another entity (Parlamentarna Skupstina Bosne i Hercegovine, 2009). The Constitution has also established a procedure for reaching agreement, according to which a 3member committee (one member from each entity) requires a consensus within 5 days, and if that does not happen the Constitutional Court is the final authority for assessing the decision whether it is in contradiction with the vital national interests of the complaining entity or not. Although is unique, this constitutional arrangement can be compered with Belgium “Alarm Bell Procedure” (Kelleher, 2005).

The fact that the federal constitution has not determined what the vital national interests are makes the right of mutual veto to be a serious obstacle to the creation of

4 The Dayton Agreement was reached in November 1995 at Dayton, Ohio, USA, and was signed in December of that year. More on this agreement see: https://www.osce.org/bih/126173?download=true 
federal legislation. As an illustration, we are mentioning that in the period of 1997-2007 out of 529 laws reviewed, 269 of them did not get the majority of the deputy votes due to the veto of representatives of either entity (Gavrić, Banović and Barreiro, 2013). As we have seen above, in Kosovo the situation is much more favorable, at least for two reasons: First, the Kosovo Constitution has explicitly defined what are the laws that may affect vital national interests, which are also require the vote of the majority of representatives of non-majority communities present and voting. Secondly, while the mutual veto in Bosnia and Herzegovina maintains and deepens ethnic division, the veto of non-majority communities in Kosovo encourages inter-minority co-operation among non-majority communities, and also political consensus with the Albanian majority.

Regarding constitutional changes, federal constitutional arrangements require amendments to be voted on by $2 / 3$ of the representatives in the federal Assembly. This means $2 / 3$ of the attendees in the Chamber of Representatives and 2/3 in the Peoples' Chamber. Unlike the case of Kosovo, which expressly requires 2/3 of all MPs, including 2/3 of MPs of non-majority communities.

At first, the impression is that the Constitution of Bosnia and Herzegovina can be easily changed, especially when realizing that the Parliamentary Assembly is dominated by Bosniaks and Croats, who can easily make a majority of $2 / 3$. This majority can be achieved both in the representative and the people's chambers. In fact, in the current allocation of seats in parliament, the representative chamber has 42 MPs, of which the Croatian and Bosniak entity is represented by 28 representatives, and the Serbian entity with 14 MPs. Likewise, in the Peoples' Chamber, out of a total of 15 MPs, 10 seats belong to Bosniaks and Croats, and 5 to Serbs. So, in both cases, the Bosnian and Croat entities make up a qualified majority. However, the fact that the constitution amendment comes as a parliamentary decision, the representatives of any of the entities can use the right of veto to protect national interests and hinder the change. The fact that so far, only one amendment has been adopted, speaks for itself. ${ }^{5}$

A similar situation prevails also at the entity level, with the only difference that in their constitutions issues for which a veto may be used to protect national interests are expressly defined. Changing the constitution also requires a majority of $2 / 3$ in the representative chamber and majority of each entity in the peoples' chamber. While in the federal entity two-thirds of the members of the constitutional Assembly are required, seeking the consensus of the majority of Serbian and Croatian representatives.

\section{III.2.Republic of North Macedonia}

North Macedonia is another case of the implementation of the concept of democratic democracy, which, despite all the difficulties still following, has brought major changes to the North Macedonian political system and has provided lasting peace

\footnotetext{
5 It is about the Amendment, which clarifies the powers of the Constitutional Court regarding the Brcko District. This amendment was adopted in 2009.
} 
for as long now. This model was provided by the "Ohrid Accord", ${ }^{6}$ reached between representatives of the major Macedonian and Albanian political parties, with international mediation. North Macedonia, as well as Kosovo, has maintained the unitary character of the state, but with a solid degree of decentralization. In addition to decentralization, the agreement also imposes a proportional electoral system, which provides relatively proportional representation of ethnic communities, proportional representation in public administration bodies and public enterprises, as well as an application of the so-called "Badinter majority". ${ }^{7}$ In fact, here we are concerned with a suspensive veto of non-majority communities, which, as in Kosovo, means "a double majority".

Unlike the case of Kosovo, where the government of an inter-ethnic coalition is a compulsory, the Macedonian Constitution does not require a government of a broad interethnic coalition, though political needs have created a practice of joint AlbanianMacedonian governance.

The minority veto, in the form of a "double majority", according to the Northern Macedonian constitution can be used regarding three issues. First, pursuant to Article 69, paragraph 2, for the adoption of laws dealing with culture, use of language, education, personal documents and use of symbols, a majority of the votes of the present deputies, including the majority of votes of the present members of nonmajority communities are required. As compared to Kosovo, we see similarities with the same majority and the same way of voting, though not with regard to the issues to which this veto or majority applies. In the case of Kosovo, as we have said above, there is a wider range of issues that require a double majority. However, the Constitution of the Republic of North Macedonia, in Article 78, has established an interethnic committee consisting of 19 members and which, in addition to examining the issues of relations between communities, also decides on cases when a special procedure for the use of the double majority is contested. So if the majority in the parliament object to the application of the double majority, on the pretext that it is not part of the areas of vital national interest, then the interethnic committee decides with a majority of votes of its members. The fact that the Committee consists of 7 Macedonians, 7 Albanians, and 5 representatives of other communities (1 Turkish, 1, Bosniak, 1 Serb, 1 Roma and 1 Vlach) allows for the non-majority communities to consider issues of vital national interest and any other issue, which is not explicitly mentioned in the Constitution. Kosovo also has a Consultative Council for Communities, though it is a consultative institution and within the office of the President without a constitutional power like that of the Macedonian inter-ethnic parliamentary committee. The Ombudsman is elected only on a majority of all MPs voting, though on condition that within this majority there must be a majority of all members of the non-majority communities. Otherwise, in

6 The Ohrid Framework Agreement was signed on 13.08.2001 ending the armed conflict between the National Liberation Army and the Macedonian Army.

7 It was so named, according to the name of French lawyer Robert Badinter, who in 1991 was head of the Arbitration Commission for Yugoslavia and later engaged in the drafting of the Ohrid Agreement. 
Kosovo, voting for the ombudsman is subject to a usual voting procedure, which requires only a majority of all deputies.

Regarding the election of members of the Judicial Council, out of 15 members, 5 members only opt for the double majority, while others are elected by the judges themselves. In the case of Kosovo, the Judicial Council is composed of 13 members, of whom 5 members are elected by the judges themselves, while 8 members are elected by the Assembly of Kosovo, of which 4 should be elected by MPs of non-majority communities. As for the members of the Constitutional Court, the Parliament of North Macedonia is an electoral authority and it elects its nine members. Six of them are elected by the majority of the votes of all MPs, and three members by most MPs, though the majority of the representatives of non-majority communities should also be included in this majority. Otherwise, in Kosovo the Assembly is only a proposing authority, and the appointment is made by the President. However, the proposals of 9 members should be voted in the Assembly through the following procedure: 7 members are proposed with the approval of 2/3 of the present and voting MPs, while the other 2 members are proposed with the approval of the majority of the present and voting MPs, though only with the consent of the majority of MPs of non-majority communities.

Finally, both in the case of North Macedonia and the case of Kosovo, a minority veto has been applied to constitutional amendments, but with essential differences. In the Republic of Noth Macedonia, the constitution can be amended on 2/3 of all MPs, only on issues of vital interest to communities (education, language, culture, local selfgovernment and the like) requiring within the majority of $2 / 3$ a majority of $2 / 3$ of the non-majority communities. On the other hand, in the case of Kosovo, constitutional amendments are considered adopted only if they have the votes of 2/3 of all deputies, but on condition that these two thirds contain also 2/3 of MPs of non-majority communities on whatever matters (Constitution of Macedonia, 2005).

So, in the case of Kosovo, the right of minority veto is absolute and unlimited on issues of vital interests for minorities. It can be used even against changing a single word in the Constitution. This power of minority right in Kosovo makes it special and not typical in comparison with the right of the minority veto in the case of consociational democracies, even with most "consolidated one, like Belgium” (Lijphart, 1981).

In comparision we can conclude that in Belgian democracy, a minority veto is constitutionally guaranteed only for matters of vital interest to constitutive communities (Belgian House Of Reresentatives, 2017). Even the so called "Alarm Bell Procedure" is in the function of a "soft veto power", and can not block the constitutional changes in general. This procedure can only provide consensus opportunities for issues of vital interest. 


\section{IV.CONCLUSIONS}

A comparative analysis of minority veto rights in all three cases of study provides some clear and direct (explicit) conclusions, and also indirect or implicit implications.

First, the veto of non-majority communities in Kosovo, related to legislation, is a strong shield of their vital national interests and in the function of democratic governance. The range of national interests is wider than in other cases analyzed here and, moreover, it is clearly defined on the constitution.

Secondly, the veto of the non-majority communities on constitutional changes is a specific arrangement, unprecedented in consociational democracies, as in the case of Kosovo, the approval of any constitutional change cannot be made without the consent of $2 / 3$ of the representatives of non-majority communities.

Third, the veto in the constitutional changes also conflicts with the principles of consensual democracy, which does not allow minorities to block the governing of the majority, the less so disputing the sovereignty of the people.

Fourthly, although Kosovo is not a typical multiethnic society, the application of the model of consociational democracy has produced results, especially in achieving common interethnic governance and more proportional representation (especially Serbian representation) of all communities in Kosovo.

Finally, the minority veto on constitutional changes, in the way it is regulated by the current Constitution of Kosovo, may hinder the consolidation of the state and democracy. Its modification through a constitutional change procedure is impossible, therefore it requires a political approach, which should be aimed at the consent of its non-majority communities, so that their veto right is restricted to matters of vital interest national.

\section{REFERENCES}

Antonini, C. (2014) 'Multinational Federalism in Bosnia and Herzegovina Keil, Soeren Farnham, Surrey, Ashgate (2013), 219 p., ISBN 978-1-409-45700-8', Swiss Political Science Review. doi: 10.1111/spsr.12111.

Baliqi, B. (2018) 'Promoting Multi-Ethnicity or Maintaining a Divided Society: Dilemmas of Power-Sharing in Kosovo', Journal on Ethnopolitics and Minority Issues in Europe.

Belgian House Of Reresentatives (2017) The Belgian Constitution. Belgium House of Reresentatives.

Bieber, F. and Keil, S. (2009) 'Power-sharing revisited: Lessons learned in the Balkans?', Review of Central and East European Law. doi: 10.1163/092598809X12474728805778. 
Bojkov D. Victor (2003) 'Democracy in Bosnia and Herzegovina: Post-1995 Political System and its Functioning', Southeast European Politics, IV(1), pp. 41-67.

Constitution of Macedonia (2005). Assambly of Macedonia.

Gavrić, S., Banović, D. and Barreiro, M. (2013) The political system of Bosnia and Herzegovina Institutions - actors - processes. Sarajevo: Sarajevski otvoreni centar/Sarajevo Open Centre.

Interim Agreement for Peace and Self-Government in Kosovo (1999). Rambouillet, France.

Kasapovic, M. (2005) 'Bosnia and Herzegovina: Consociational or Liberal Democracy’, Politicka misao, XLII(5), pp. 3-30.

Kelleher, S. (2005) 'Minority Veto Rights in Power Sharing Systems: Lessons from Macedonia, Northern Ireland and Belgium’, Adalah’s Newsletter, 13, pp. 6-7.

Korenica, F. i Doli, D. (no date) 'THE POLITICS OF CONSTITUTIONAL DESIGN IN DIVIDED SOCIETIES: THE CASE OF KOSOVO', Croatian Yearbook of European law \& Policy, 6((6)), pp. 265-292.

Kosovo Assambly (2008) Constitution of Kosovo. Kosovo.

Kosovo Assambly (2010) Low on the Civil Service.

Kosovo Assambly (2012) Gazeta zyrtare e Reublikës së Kosovës. Kosovo.

Kosovo Assembly (2008) Low on Local Sel Governmant.

Lijphart, A. (1981) Conflict and Coexistence In Belgium : the Dynamics of a Culturally Divided Society. Edited by A. Ljiphart. University of California Berkeley. Institute of international studies.

Ljiphart, A. (1977) Democracy in Plural Societies-Comparative Exploration. New Haven and London Yale Univerisity Press.

Loncar, J. (2015) Power-sharing in Kosovo: Effects of Ethnic Quotas and Minority Veto. In:J. Teokarević, B. BaliqiandS.Surlić(ed.)Perspectivesofa Multiethnic Society in Kosovo (5) Power-sharing in Kosovo: Effects of Ethnic Quotas and Minority Veto | Request PDF. Available.

McGarry, B. O. and R. S. (2008) 'The Integration-Accommodation Debate: An Outline' Constitutional Design for Divided Societies: Integration or Accommodation? Edited by S. Choudhry. New York: (OUP, Oxford 2008).

Parlamentarna Skupstina Bosne i Hercegovine (2009) Ustav Bosne i Hercegovine (Opšti okvirni sporazum za mir u Bosni i Hercegovini - Aneks IV) i Amandman I na Ustav Bosne i Hercegovine. Bosnja i Hercegovina.

Ramadani, B. (2009) Shteti i komuniteteve: Në zbatim të modelit të Ahtisarit.

UNMIK/REG/2001/9 (2001) REGULATION No. 2001/9 ON A CONSTITUTIONAL FRAMEWORK FOR PROVISIONAL SELF-GOVERNMENT IN KOSOVO. 